"Management information used by Spanish Airlines for the financial decision making process: an exploratory study"

\begin{tabular}{ll} 
& $\begin{array}{l}\text { Fernando Campa-Planas } \\
\text { Nicole Kalemba } \\
\text { Lucía-Clara Banchieri } \\
\text { Juan Magaz-Pérez }\end{array}$ \\
\hline ARTICLE INFO & $\begin{array}{l}\text { Fernando Campa-Planas, Nicole Kalemba, Lucía-Clara Banchieri and Juan } \\
\text { Magaz-Pérez (2016). Management information used by Spanish Airlines for the } \\
\text { financial decision making process: an exploratory study. Investment Management } \\
\text { and Financial Innovations, 13(3-2), 341-352. doi:10.21511/imfi.13(3-2).2016.06 }\end{array}$ \\
\hline DOI & http://dx.doi.org/10.21511/imfi.13(3-2).2016.06 \\
\hline RELEASED ON & Monday, 10 October 2016 \\
\hline JOURNAL & "Investment Management and Financial Innovations" \\
\hline FOUNDER & LLC "Consulting Publishing Company "Business Perspectives"
\end{tabular}

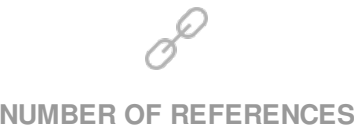

0

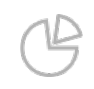

NUMBER OF FIGURES

0

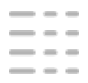

NUMBER OF TABLES

0

(C) The author(s) 2023. This publication is an open access article. 


\title{
Management information used by Spanish Airlines for the financial decision making process: an exploratory study
}

\begin{abstract}
The main objective of this research was to examine the degree of practical application of management accounting in Spanish airline companies as far as management accounting is a crucial tool for the financial decision making process. In particular, the goal was to get to know the degree of strategic planning, the utilized methods of budgeting, procedures used to present the comparison between planned and actual results, and the reported key performance indicators, as well as their frequency. Quantitative methodology has been used through the creation of an on-line questionnaire. The results showed that the level of implementation, and utility granted to the different techniques of management accounting in the analyzed companies that are corresponding to the six most important airlines in Spain, is pretty high, helping airline companies to make operations and financial decisions.
\end{abstract}

Keywords: strategic planning, airline companies, financial decision making, key performance indicators, management accounting.

JEL Classification: M41, L93.

\section{Introduction}

The international air transport industry is essential for any global economy as it provides a great value and service to operate in a completely globalized environment (Belobaba et al., 2009). Numerous studies have shown that air transport contributes significantly to the economy of a country, being an important motor for the economic development of the nations (Button et al., 1998; Reynolds-Feighan, 2001; Daley, 2009; Ginieis et al., 2012), as well as for the social development (ATAG, 2014; IATA, 2014).

The growth of the air transportation industry during much of the twentieth century was made possible by major technological innovations, such as the introduction of aircrafts for commercial use in the 50 s, followed by the development of wide-body aircrafts in the 70s (Belobaba et al., 2009), among other actions. To emphasize the importance of the sector by volume, currently the airline industry consists of 1,397 airline companies, operating 25,332 aircrafts, and providing service to 3,864 airports worldwide (ATAG, 2014).

Air transport differs from other types of transportation due to characteristics such as speed, safety and security, flexibility and cost (ATAG, 2014). One of the most widely used indexes to measure the efficiency of air transport is its passenger load factor, which was $80.2 \%$ worldwide in 2015 (IATA, 2016). The air traffic passenger

(C) Fernando Campa-Planas, Nicole Kalemba, Lucía Clara Banchieri, Juan Magáz Pérez, 2016.

Fernando Campa-Planas, Ph.D., Full Professor, Universitat Rovira i Virgili (Reus), Spain.

Nicole Kalemba, Ph.D. Student, Universitat Rovira i Virgili (Reus), Spain.

Lucía-Clara Banchieri, Ph.D., Associate Professor, Universidad Nacional del Sur (Bahía Blanca), Argentina.

Juan Magáz-Pérez, Specialist Consultant in Air Transport, Spain. demand is steadily growing and it is expected that the airline sector will maintain a positive compound annual growth rate (CAGR) of 5.4\% until 2017 and afterwards a slight increase will be maintained until 2030 (IATA, 2015; Statista, 2015).

According to the Air Transport Action Group (ATAG, 2014), the rapid growth of air transport in recent decades has been motivated mainly by the following factors:

- Increase of GDP, disposable income and quality of life, which has led to an increase in the demand for traveling, with a consequent impact on the sector.

- Reduced airfares, as a result of improved efficiency in the sector and higher competition, increasing, therefore, the demand by offering a higher and easier accessibility to the purchase of flight tickets.

- Globalization of the sector, through the increase of long-distance trips offered, consequently, providing a better infrastructure and better equipped aircrafts for long haul flights.

- Deregulation of the sector, by making possible the entry of new companies in the sector, additionally to the traditional flag carriers. Starting in 1978 in the United States, the economic deregulation was a key event for the industry, concepts such as cost efficiency, operational profitability and competitive behavior became dominant issues that the airline management (Belobaba et al., 2009).

As a result of the mentioned continuous development of the airline industry, its growing complexity and the highly competitive environment, it is essential to consider management accounting as it helps managers to make decisions, to solve problems, to plan related activities, as well as it 
helps to follow up and control them. And certainly, it is necessary to know, in which way airlines are managing their resources and how they run their operations. The existing global competition in the market of firms has increased steadily the number of challenges the managers are confronted with (PérezMéndez and Machado-Cabezas, 2015).

\section{Objective of the study}

As literature on the relevance of management accounting in the airline industry is scanty, the objective of this research was to analyze management information used by Spanish Airlines, carrying out an exploratory study.

Spain is the second ranked tourist destination in Europe and the third in the world in numbers of international tourist arrivals (UNWTO, 2016) and, obviously, the air transport plays an indispensable role as intermediary industry in the tourism sector, so that in 2014 , a $79.7 \%$ of the international tourists used the airplane as means of transport for arriving to Spain. Also the fact that Spain provides about 3.88 billion seat kilometers weekly (Statista, 2015), made that all those mentioned aspects have been seen as potential factors to put an emphasis on the main regular Spanish airline companies in this research.

\section{Structure of the paper}

Therefore, the paper gives initially an overview on the airline industry, both in a general way, as well as specifically in the case of Spain. Section 2 describes the need of management accounting in general terms, as well as in the air transport sector. Section 3 presents the goals and methodology applied, section 4 exposes the results of the exploratory study, while the last section explains the concluding remarks.

\section{An overview on the airline industry}

1.1. Relationship between the air transportation and economic activity. Air transport generates employment in the airline sector and creates wider socioeconomic benefits thanks to its potential of combining various types of activities in a local economy, consequence of the increasingly globalized world economy, facilitating the growth of international trade, tourism, and, consequently, international investment (ATAG, 2014).

This economic impact of the airline industry varies from its direct effects on employment and profitability of the companies, to the less direct, but important effects on aircraft manufacturing, construction of infrastructures and airport management. The air transportation industry has also an important impact on the tourism industry and contributes significantly to the development of other industries or activities (Belobaba et al., 2009; AECA, 2011).
Economic activity generates the need of transportation of passengers and goods and, therefore, urges a high demand on air transport services. This relationship results in a significant correlation between the amount of air travelers and the global GDP (Ishutkina and Hansman, 2008).

Consequently, the air transportation industry is a global driver of the economy and, as an outcome thereof, more than 58 million jobs have been created, contributing a 3.4\% of the global GDP (ATAG, 2014).

1.2. The air transportation sector in Spain. Spain, whose economy is significantly oriented to the service and tourism sector, companies involved in the air transportation industry are essential for the performance of the country's economy, being a basic pillar of its development (CEOE, 2009).

It is one of the activities that shows a greater contribution to the GDP of the country, 6\% (INE, 2011), and plays an important role as an intermediary industry (AECA, 2011). There is an important link between air transportation and international trade of goods and generation of services, promoting specially the tourism (AECA, 2011).

As previously mentioned, Spain is the third country in the world and second in Europe by international tourist arrivals in 2015 (UNWTO, 2016).

As it is shown in Figure 1, during the years 19972014, the movement of passengers (arrivals and departures) in Spanish airports has had an upward trend, with exceptions in the years 2002, 2008/2009 and $2012 / 2013$, periods which coincide with the cycle of the worldwide recession, before mentioned.

The year 2007 stands out with an historic record of 210.5 million passengers, followed by two consecutive years of declines with annual variations of a $-3.2 \%$ and $-8 \%$, respectively, caused by the increase in fuel price and the beginning of the global financial crisis having a significant impact on the Spanish economy (Hosteltur, 2013).

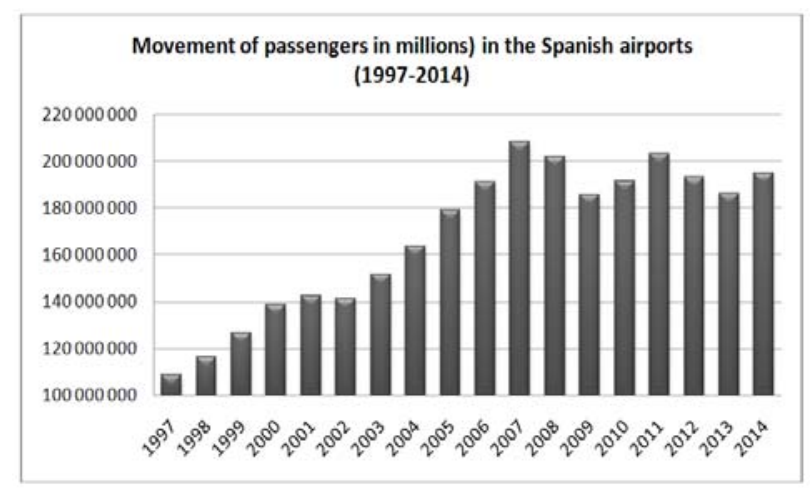

Source: created by the authors from the data of the Ministry of Public Works and Transport, 2015.

Fig. 1. Movement of passengers (in millions) in the Spanish airports (1997-2014) 
The main flow of passengers from Spain is related to the traffic it has with the European Union (see Figure 2), which represents approximately $64 \%$ of the total movement, followed by $21 \%$ of the domestic market, whereas the extra European market represents 15\% (Hosteltur, 2013).

Distribution of transported passengers 2012

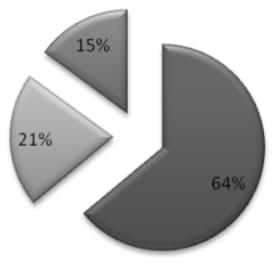

European Union

$\square$ Domestic

Extra EU

Source: created by the authors from the data of the Ministry of Public Works and Transport, 2013.

Fig. 2. Distribution of transported passengers from Spain, 2012

Additionally, it is important to mention that, apart from the deregulation in the air transportation sector, there were other factors that have had a significant impact on the airline industry, including the construction of new road infrastructure, new market participants, such as Low Cost Carriers (henceforth LCCs), and the competence of the high speed train (being called AVE in Spain). The latter has led to a major shift in the air traffic demand to the train, especially the domestic one (Albalete et al., 2014), since it is a clear alternative to air and road transport. The high speed train services can replace the air transport services and they are more competitive, especially on short-haul routes (Givoni and Banister, 2006).

An example in Spain is the high speed train route between Madrid and Barcelona, which was launched in February 2008 and reached, in 2015, a traffic volume of more than 3.7 million of passengers (City Council Barcelona, 2015), being market leader on this route (Hosteltur, 2013).

1.3. Main national and international airline companies in Spain. Table 1 shows a ranking of the major domestic and international airlines that operate in Spain along with their numerical evolution of the number of passengers carried during the years 2004, 2008 and 2014.

Table 1. Evolution of the number of passengers by each airline company

\begin{tabular}{|l|c|c|c|c|c|c|}
\hline & \multicolumn{2}{|c|}{2004} & \multicolumn{2}{c|}{2008} & \multicolumn{2}{c|}{2014} \\
\hline Vueling & 609.077 & $0,4 \%$ & 7.747 .831 & $3,8 \%$ & 26.913 .436 & $13,8 \%$ \\
\hline Air Europa & 13.160 .608 & $8.0 \%$ & 15.652 .406 & $7.7 \%$ & 14.844 .608 & $7.6 \%$ \\
\hline Iberia & 41.307 .515 & $25.2 \%$ & 33.647 .618 & $16.6 \%$ & 13.348 .083 & $6.8 \%$ \\
\hline Air Nostrum & 6.677 .152 & $4.1 \%$ & 9.595 .041 & $4.7 \%$ & 6.648 .928 & $3.4 \%$ \\
\hline Iberia Express & & & & & 6.130 .541 & $3.1 \%$ \\
\hline Binter Canarias & 4.876 .146 & $3.0 \%$ & 4.663 .981 & $2.3 \%$ & 453.785 & $0.2 \%$ \\
\hline Volotea & & & & 306.845 & $0.2 \%$ \\
\hline Pullmantur Air S.A. & 94.547 & $0.1 \%$ & 281.533 & $0.1 \%$ & 183.429 & $0.1 \%$ \\
\hline Swiftair S.A. & 25.658 & $0.0 \%$ & 245.545 & $0.1 \%$ & 16.337 & $0.0 \%$ \\
\hline Flightline (Flight-Avia) & 6.354 & $0.0 \%$ & 11.724 & $0.0 \%$ & 1.048 & $0.0 \%$ \\
\hline Rest of Spanish companies & 35.198 & $0.0 \%$ & 444.590 & $0.2 \%$ & 2.822 .099 & $1.4 \%$ \\
\hline Subtotal Spanish companies & 66.792 .255 & $40.8 \%$ & 72.290 .269 & $35.7 \%$ & 71.669 .139 & $36.8 \%$ \\
\hline Ryan Air & 3.765 .229 & $2.3 \%$ & 14.871 .089 & $7.4 \%$ & 31.698 .195 & $16.3 \%$ \\
\hline Easy Jet & 5.645 .087 & $3.4 \%$ & 10.999 .798 & $5.4 \%$ & 10.679 .112 & $5.5 \%$ \\
\hline Air Berlin & 6.975 .791 & $4.3 \%$ & 11.604 .998 & $5.7 \%$ & 9.506 .757 & $4.9 \%$ \\
\hline Norwegian Air & 59.182 & $0.0 \%$ & 405.924 & $0.2 \%$ & 4.690 .874 & $2.4 \%$ \\
\hline Thomson Airways & 173.413 & $0.1 \%$ & 4.324 .592 & $2.1 \%$ & 4.180 .404 & $2.1 \%$ \\
\hline Rest of foreign companies & 80.477 .560 & $49.1 \%$ & 87.726 .534 & $43.4 \%$ & 62.553 .729 & $32.1 \%$ \\
\hline Subtotal foreign companies & 97.096 .262 & $59.2 \%$ & 129.932 .935 & $64.3 \%$ & 123.309 .071 & $63.2 \%$ \\
\hline Total traffic Spanish airports & 163.888 .517 & $100.0 \%$ & 202.223 .204 & $100.0 \%$ & 194.978 .210 & $100.0 \%$ \\
\hline
\end{tabular}

Source: created by the authors from the data of AENA, 2015.

Of the six major regular Spanish airlines, Vueling is the one with the highest number of passengers transported in 2014, followed by Air Europe and Iberia. In the case of the international airline companies, the evolution of Ryanair stands out during the years 2004-2014 as, in the last year, it was the company with the highest number of transported passengers in Spain. Although the total number of traffic at Spanish airports has had an evolution with a positive tendency, we observed a change in the market share obtained by the Spanish and international airlines over the total of transported passengers during the analyzed period. In 2004, $40.8 \%$ of all the passengers were transported by the Spanish airlines, whereas this percentage was reduced in 2014 to $36.8 \%$, while foreign companies had an increase in the opposite direction in the market share they obtained. 


\section{The need of management accounting}

2.1. Management accounting as a financial tool. The term management accounting started to be used in Spain in the decade of the 80s to define new fields of action which arise within the discipline of cost accounting, and, given its scope and relevance it contributes in an outstanding way with a new terminology to the countable disciplines, causing a new approach of objectives and methodology.

Already in 1969, the Institute of Management Accounting (IMA, 2016) defined the targets of these accounting fields in the United States as follows:

- Managing functions that are critical to business performance.

- Supporting organizational management and strategic development.

- Providing accurate and insightful information for better decisions.

- Ensuring that organizations operate with integrity and proper governance.

- Planning for the long-term and helping to ensure sustainability.

- Safeguarding the interests of the organization and its key stakeholder.

AECA ${ }^{1}$ (AECA, 1990) defines management accounting as a branch of accounting that aims to capture, measure and assess, as well as to rationalize and control the internal data, in order to provide information to the organization that is relevant for making decisions in the business. Therefore, the aim of management accounting is to give answers to multiple needs formulated in organizations, in order to optimize cost efficiency and, therefore, to be more competitive from the strategic and financial point of view.

The expected information from management accounting should allow adopting decisions rationally, so that the risk that emerges from this decision can be as small as possible. This information is expected to be used as a guide or baseline for all types of internal company decisions. According to Lebas (1993), management accounting avoids all kinds of submission to any regulation since it is inserted closer to the ambiguous and imprecise future, than to the past.

Therefore, management accounting is one of the basic instruments for the process of decision making in business organizations and the control they require (Sáez et al., 1993), having experienced a spectacular evolution in the last decades. The transformation processes of organizations, the interaction with the environment, both economic and social, the new

\footnotetext{
1 Spanish Association of Accounting and Business Administration (www.aeca.org).
}

competitive context and the incorporation of new technologies have greatly influenced this development (Fernández, 1994).

In this context, Porter (1996) says that a company that wants to be competitive and sustainable in the long term should achieve operational efficiency and have a clear strategy. As explained in the previous section, deregulation in the airline industry increased even more the importance of the exposed issues for the airline companies (Belobaba et al., 2009).

Management accounting contributes to operational efficiency through monitoring and controlling costs. From a strategical and financial perspective, it provides the link between the budget and the strategic plan that ensures that the financial resources are related and oriented to the achievement of the final goals of the organization.

With this in mind, special features of tools and management accounting models used by the airline companies will be presented.

\subsection{Management accounting in the air transpor-} tation sector. Decision making and planning is a crucial task within the management accounting and especially in the airline industry as this sector is highly competitive. Through an effective organizational structure, one company can have an advantage over another one (Wensveen, 2015).

The airline business involves a multitude of other businesses as passenger and cargo transportation and handling, airport infrastructures, information systems, catering, ancillaries (O'Connell and Warnock, Smith, 2013), between others (CampaPlanas and Campa-Lewkowycz, 2009; AECA, 2011), fact that makes management accounting indispensable in such a complex industry as aviation is. Furthermore, it provides information especially to managers and employees about financial and operating data of organization's activities.

The air transportation sector has a number of characteristics different to other businesses and related to their management that should be known and considered (AECA, 2011):

- Operates in a global market with no significant entry barriers.

- There exist (more or less visible) state aids that distort supply conditions of the companies of the sector.

- High structure of fixed costs, forcing them to maximize the total revenues per flight.

- Important power of negotiation of the suppliers of goods and specific services.

- The economic results of the airlines are low; seldom do they offer positive results and, in any case, they do not reach to compensate the cost of capital. 
2.2.1. Costs in air transportation. The most practical classification of costs for decision making and analysis is based on the concepts of operating and non-operating costs, direct and indirect costs, and finally fixed and variable costs (AECA, 2011). Table 2 shows the structure followed by most of the airline companies operating in the market.

Table 2. Classification of costs used by the airline companies

\begin{tabular}{|c|c|l|l|}
\hline \multirow{4}{*}{$\begin{array}{c}\text { Total } \\
\text { costs }\end{array}$} & $\begin{array}{c}\text { Non-operating } \\
\text { costs }\end{array}$ & & \\
\cline { 3 - 4 } & \multirow{2}{*}{ Operating costs } & Direct operating costs & Fixed \\
\cline { 3 - 4 } & & $\begin{array}{c}\text { Indirect operating } \\
\text { costs }\end{array}$ & Variables \\
\cline { 3 - 4 } & & Fixed \\
\hline
\end{tabular}

Source: AECA (2011).

1. Non-operating costs: costs that are not related to the operations of air transport, for example, financial costs.

2. Operating costs: those that are caused by the activity of air transport. These costs are divided into direct and indirect costs.

2.1 Direct costs are those that can be linked unequivocally to passengers or to the aircraft. These costs, in turn, are divided into fixed and variable costs.

2.1.1 Direct and fixed costs: costs of the aircraft, fixed costs of maintenance, handling structure to passengers in the airport, fixed costs of the crews, fixed commercial costs, among others.

2.1.2 Direct and variable costs: fuel, airport taxes, ramp handling, variable costs of maintenance, variable costs of the crews, compensation for passengers, compensation for the loss of luggage, service on board, among others.

2.2 The indirect costs are fixed or variable depending mainly on the time domain. Among indirect operating costs are: cost of the maintenance engineering area, cost of the area of technical flight direction and the cost of the overall structure.

From another perspective, the costs in the air transportation industry can also be classified as requested by the ICAO (International Civil Aviation). This institution requires periodically the costs of all the airline companies in each of the markets with the objective that the companies carry out benchmarking. The collected information is, then, supplied to each company for its analysis.
The classification is as follows:

1. Costs by type of aircraft and type of route.

2. Costs by geographic area.

3. Other operating expenses.

4. Other non-operating expenses.

2.2.2. Strategy and budget. Porter (1985) identifies generic strategies for any industrial sector: differentiation, cost leader and segmentation. In the air transportation sector, the big companies with the core business of passenger transport (without forgetting the important involved businesses) are divided in the following classifications, adapting the denominations of network, low cost and charter airlines, respectively. It should be noted that both, LCCs and network airlines, have, in general terms, the same need of using management accounting as a tool for the decision making process, but using different key performance indicators (KPIs) as far as the strategic points of their businesses are different.

Upon this, Table 3 presents distinctive characteristics, on the one hand. of an airline that has a differentiation strategy and. on the other hand. an airline leading in costs.

Table 3. Distinctive characteristics of strategy used by network airline and LCC

\begin{tabular}{|c|c|c|}
\hline Characteristics & Low cost carrier & Network airline \\
\hline Image to transmit & Price & Price and quality \\
\hline Price & Simple price structure & Complex price structure \\
\hline Distribution & $\begin{array}{l}\text { Internet, direct } \\
\text { purchase }\end{array}$ & $\begin{array}{l}\text { Internet, direct } \\
\text { purchase, travel agency }\end{array}$ \\
\hline Checking in & No ticket & $\begin{array}{l}\text { No ticket, IATA ticket } \\
\text { contract }\end{array}$ \\
\hline Airports & $\begin{array}{l}\text { Mostly secondary } \\
\text { airports }\end{array}$ & Main airports \\
\hline Business & Point-to-point & Hub-and-spoke \\
\hline Class & Only one class & Multiple classes \\
\hline During the trip & Paying for services & Free services \\
\hline Use of aircrafts & Very intensive & Moderate-intensive \\
\hline Type of aircraft & $\begin{array}{l}\text { One type and few } \\
\text { diversity of models and } \\
\text { brands }\end{array}$ & Multiple types \\
\hline Turnaround & 25 minutes average & Higher period of time \\
\hline Product & $\begin{array}{l}\text { A single product: } \\
\text { cheap tickets }\end{array}$ & $\begin{array}{l}\text { Multiple integrated } \\
\text { products }\end{array}$ \\
\hline $\begin{array}{l}\text { Complementary } \\
\text { product }\end{array}$ & Sales during the flight & $\begin{array}{l}\text { Focus on the main } \\
\text { product }\end{array}$ \\
\hline Seat & $\begin{array}{l}\text { Little legroom (high } \\
\text { density of seats), no } \\
\text { reservations accepted }\end{array}$ & $\begin{array}{l}\text { Extensive space } \\
\text { between the seats, } \\
\text { reservations accepted }\end{array}$ \\
\hline Customer service & Generally poor service & $\begin{array}{l}\text { Complete and reliable } \\
\text { service }\end{array}$ \\
\hline Operating activities & $\begin{array}{l}\text { Focus on business of } \\
\text { passengers }\end{array}$ & $\begin{array}{l}\text { Extensions: } \\
\text { maintenance, cargo }\end{array}$ \\
\hline
\end{tabular}

Source: O'Connell and Williams (2005).

Subsequently, Porter (1996) states explicitly that the strategic positions should have a temporal horizon higher than one decade and not only a single planning cycle. 
The achievement of the strategy requires the company to develop and try complying with a strategic plan, which is the tool that contains goals that should be achieved by the organization and the actions and policies that should be implemented to achieve them.
For a better understanding, Figure 3 provides as an example the system of activities of Southwest Airlines. This figure defines the actions chosen by the company and how they are related between each other to achieve the objectives that the organization has established in relation to their low-cost strategy.

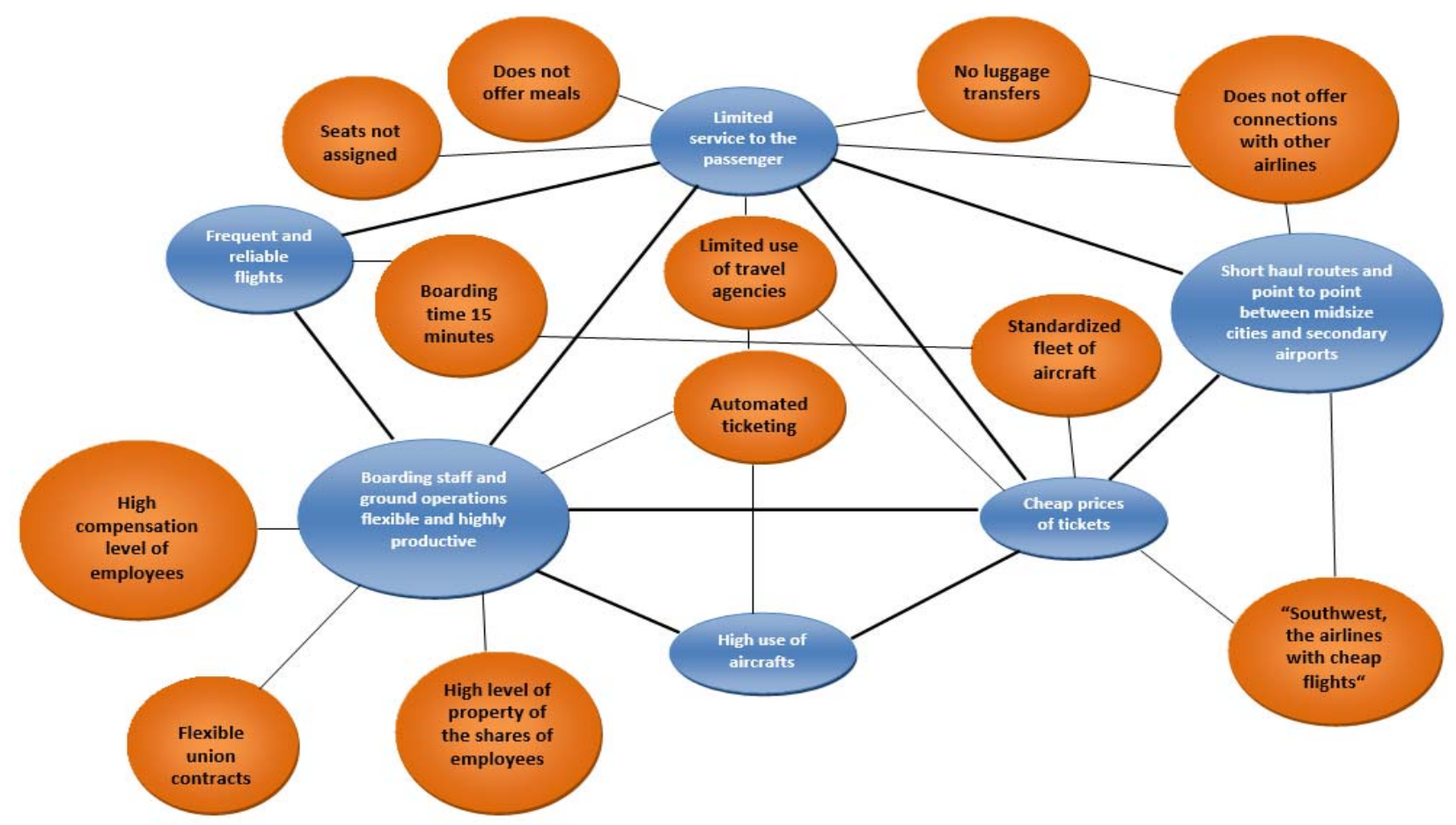

Source: created by the authors based in Porter (1996).

Fig. 3. System of activities of Southwest Airlines

The budget is a central tool in the planning process, being the quantification in monetary units of the expected evolution for a given period. Due to the changing context, companies not only carry out the budget but, on many occasions, they analyze different stages through forecasts. Likewise, once the budget has been drafted, they carry out rollings to update and adapt them to the reality. For example, Table 4 shows variables which Southwest Airlines controls to adapt its budget.

Table 4. Measures and periods Southwest Airlines uses for performing rolling forecast

\begin{tabular}{|l|c|c|c|c|c|}
\hline & Economic relevance & Variability & Speed of response & Refresh rate & Forecasted horizon \\
\hline Revenues & High & High & High & Daily & Quarterly \\
\hline Personnel costs & High & Low & Middle & Fortnightly & Biannual \\
\hline Fuel cost & High & High & Middle & Weekly & Quarterly \\
\hline Maintenance expenses & Middle & Middle & Middle & Fortnightly & Biannual \\
\hline Advertising expenses & Middle & Middle & High & Monthly & Biannual \\
\hline Costs of own fleet & Middle & Low & Low & Quarterly & Annual \\
\hline Airport fees and charges & Middle & Middle & Low & Weekly & Biannual \\
\hline Other operating costs & Middle & Middle & Middle & Fortnightly & Fortnightly \\
\hline
\end{tabular}

Source: Zeller and Metzger (2013).

The monitoring of these measures makes it easier for the company to make decisions and to achieve their goals in this dynamic and changing environment as it is the airline sector, as well as it helps the management to guide the future of the company.

\section{Goals and methodology used}

As the research goal is to get to know the degree of practical implementation of management accounting (planning, management indicators and their followup) in Spanish airline companies, thus, quantitative methodology has been used through the creation of an on-line questionnaire.

This questionnaire included dichotomous, polytomous, categorized and open questions, as well as intensity scales in some questions following the Likert scale. The questionnaire has been developed by the authors, based on a literature review, their 
own professional experience and reviewed by an expert panel. The units of analysis were the six main regular Spanish airline companies, which, in alphabetical order, are the following: Air Europa, Air Nostrum, Grupo Binter, Iberia, Volotea, Vueling Airlines.

The questionnaire was sent by e-mail through a web link to the persons in charge of management accounting of the different airline companies as they are the key managers for giving services that can lead to an improvement of decision making especially over the long term.

It was obtained $100 \%$ of answers from the companies of the selected sample, according to the criteria mentioned before.

The questionnaire was structured in different sections as follows:

a) Name and identification of the company.

b) Resources used to develop management accounting and the importance given to it.

c) Use of traditional tools of management accounting.

d) Use of planning and budgeting systems.

e) Specific management and performance indicators of the air transportation sector used in the budgeting process.

f) Information included in the reporting systems of the company and, where appropriate, included in the BSC of the company. This section pretends to analyze if the previously mentioned variables are included in the support systems for the decision making process and the level of use of the BSC.

\section{Results of the exploratory study}

In this section, the results that have been obtained from the empirical research are presented; the analysis of this research has been divided into five different parts, following the questionnaire structure.

4.1. Resources used to develop the management accounting and the importance given to it. In this first set of questions, the approach was to observe if the airline personnel in charge of management accounting consider necessary the use of it in the companies, as well as the importance and utility they give to this tool. Moreover, the level of academic qualifications of the persons in charge and the existence of professional consultants in these fields can provide us information about the importance and relevance of management accounting in the sector from another point of view.

In response to the question "Does any person on your team develop any type of management accounting?", $100 \%$ of respondents answered affirmatively, so that all entities consider that they have implemented, in a greater or lesser degree, management accounting.

With regard to the question "Which level of academic degree does the manager have?", 5 companies indicated a degree in Business Administration or Economics, while the sixth company indicated a degree closed to these branches of study. Therefore, it can be said that a high level of university education is given in relation to the responsible persons of management accounting.

In the following questions, the goal was to get to know if the company received any external support in management accounting, and, if so, where from. Half of the companies (3) indicated that they receive external advice, and, in two of them, this advice comes from the external auditor, while in one case it comes from a specialized consulting firm in the air transportation sector.

The next question was about getting to know the goals of management accounting for the different responsible parties.

In this case, the answers did not show any homogeneity among the companies, as seen in Table 5. Some possible answers were given to the respondents, and Table 5 shows the frequency of each answer (maximum potential would be 6).

Table 5. Answer to the question: utility of management accounting

\begin{tabular}{|l|c|}
\hline & $\begin{array}{c}\text { Number of } \\
\text { answers }\end{array}$ \\
\hline Information for decision making & 6 \\
\hline Information for planning and control & 5 \\
\hline Information for the company & 5 \\
\hline Information for Shareholders & 3 \\
\hline $\begin{array}{l}\text { Calculation of costs and results through responsibility } \\
\text { areas }\end{array}$ & 3 \\
\hline Cost saving projects & 1 \\
\hline
\end{tabular}

It is seen that there is unanimity in relation to the usefulness of management accounting for facilitating the decision-making process, and almost unanimity in using management accounting as a tool for planning and control and internal information for the company's management.

In the last question of this section, as indicated before, it is shown the importance given to management accounting by the different persons in charge. At this point, it should be emphasized that the questionnaire provided five possible answers (none, low, medium, high and very high), and 100\% of the answers were in the category "very high", a fact that confirms the importance of management accounting in the airline companies from the point of view of the people responsible for the management control system. 
4.2. Use of traditional tools of management accounting. This section analyzes the results obtained related to the degree of use of traditional management accounting tools, such as cost accounting, and the orgatization structured by centers of responsibility.

In a newly formulated question, the management accounting managers were asked if the company had implemented any system of cost accounting and the answer was positive in $100 \%$ of the cases.

Afterwards, it was asked what major departments the company was divided into. The results obtained are shown in Table 6. Likewise, it was asked if the analytical orgatization, on the level of management accounting, matched the al structure, and the answer was affirmative in 5 out of 6 companies.

As shown, only two companies are distinguishing the business of passenger and cargo transportation. In the remaining areas, there is total unanimity (only one company has specified that it has a "corporate" area instead of an "administration" area; so being a non-significant difference).

Table 6. Answer to the question: organization of the airline company

\begin{tabular}{|l|c|}
\hline & Number of answers \\
\hline Handling & 6 \\
\hline Maintenance & 6 \\
\hline Cargo & 2 \\
\hline Systems & 6 \\
\hline Airline & 2 \\
\hline Commercial & 6 \\
\hline Operations & 6 \\
\hline Administration & 5 \\
\hline
\end{tabular}

Given the fact that the companies are divided into different areas, as previously seen, it was formulated the question about the existence of internal charges between these areas, requesting, where appropriate, the criterion of charging used for these services. In 4 of the 6 surveyed companies, they had established a system in which transfer pricing was the criterion for charging indicated in Table 7.

Table 7. Answer to the question: criteria in determining transfer prices

\begin{tabular}{|l|c|}
\hline & Number of answers \\
\hline Market price & 2 \\
\hline $\begin{array}{l}\text { Combination of market price and } \\
\text { standard price }\end{array}$ & 1 \\
\hline Depending on the volume of assets & 1 \\
\hline
\end{tabular}

Finally, the answers to the last question of this section about the age of the currently valid cost system of the company are shown in Table 8 . As hypothesis for the answer options, it was assumed that the calendar year coincides with the fiscal year.

Table 8. Answer to the question: age of the currently valid cost system

\begin{tabular}{|l|c|}
\hline & Number of answers \\
\hline Less than 2 years & 1 \\
\hline Between 2 and 5 years & 0 \\
\hline Between 5 and 10 years & 4 \\
\hline More than 10 years & 1 \\
\hline
\end{tabular}

4.3. Use of planning and budgeting systems. In the previous sections, the importance granted to management accounting and the use of cost accounting has been verified. In this third section of the survey, the objective was to see to which degree the use of planning and budgeting systems is important, aspects analyzed through 3 questions.

All companies answered affirmatively to the question as to whether they had established a strategic plan, and the duration of the plan in all the cases was between 3 and 5 years. There is also unanimity in the revision period of this plan; of the 6 companies, 5 indicated that they review the plan annually (and the 6th one does it every two years).

Also, in 5 of the 6 airlines, they have approved in writing the annual business goals, objectives used as a base for the preparation of annual budgets. In the later question, we asked when the annual budgets were carried out and approved; results are shown in Table 9.

Reading the table, one can see that all the budgets are carried out and approved before the beginning of the fiscal year monitored, inclusively in 5 of 6 of the cases before December. It is noticed as well that there is anticipation when the budget is about to be prepared, given the fact that, in 5 of 6 cases, the process starts during the third quarter of the year, in September, and, in one case, in July, during the summer season.

Table 9. Answer to the question: time of year $\mathrm{X}$ for the preparation and approval of the budget of the year $\mathrm{X}+1$ (calendar year $=$ fiscal year $)$

\begin{tabular}{|l|c|c|}
\hline & Budgets made & Budgets approved \\
\hline July - September & 2 & \\
\hline September - November & 1 & \\
\hline September - November & 1 & \\
\hline September - December & 1 & \\
\hline October - November & & 1 \\
\hline November & & 1 \\
\hline November - December & & 1 \\
\hline December & 1 & 3 \\
\hline
\end{tabular}

Table 10 shows the answers in regards to the starting point of the budget preparation. 
Table 10. Answer to the question: starting point of the budget preparation

\begin{tabular}{|l|c|}
\hline & Number of answers \\
\hline $\begin{array}{l}\text { From the reality of the previous year (incremental } \\
\text { budget) }\end{array}$ & 2 \\
\hline Zero based budgeting & 2 \\
\hline $\begin{array}{l}\text { Zero based budgeting for certain activities and/or } \\
\text { services. For structural costs the incremental } \\
\text { budget is used, depending on the outcome of the } \\
\text { previous year }\end{array}$ & 3 \\
\hline $\begin{array}{l}\text { From the reality of the previous year plus the fixed } \\
\text { goals in the multiannual budget for this year }\end{array}$ & 3 \\
\hline
\end{tabular}

The responses sum up more frequencies (10) than analyzed companies (6), due to the fact that more options were allowed due to the possibility of combining the criterion of budgeting based on each item in question. The frequencies are quite divided; unanimity does not exist in the base of budgeting, combining in very similar frequency the zero-based criterion and the incremental budget, with or without multi-year targets of reduction/increase.

In another question, we asked about the revision of budgets during the financial year in regard to the performance of the company. In this case, $100 \%$ of the companies responded affirmatively. And, finally, the following questions were proposed:

- Do you calculate the deviations between budget and actual results?

- Do you analyze the reasons that have generated these deviations in order to propose corrective measures, where appropriate?

- Do you carry out an analysis of deviations by price, volume and mix effect?

All the companies have answered affirmatively to all the three questions regarding the analysis of deviations.

\subsection{Specific management and performance indicators of the air transportation sector used in the budgeting process. This first set of questions in this section are intended to detect the main management indicators used by the responsible persons in control of the airline companies, as well as the frequency in obtaining and analyzing them. Table 11 details the management indicators and their frequency of carrying out annual operating budgets of the companies.}

Table 11. Management indicators and detail in the operational budgeting

\begin{tabular}{|c|c|c|c|c|c|c|}
\hline & \multicolumn{6}{|c|}{ Number of answers } \\
\hline & Not calculated & Daily & Weekly & Fortnightly & Monthly & Other \\
\hline ASK's & & 2 & & & 4 & \\
\hline RPK's & & 2 & & & 4 & \\
\hline PAX load factor & & 3 & & & 3 & \\
\hline Revenues per RPK & & 2 & & & 4 & \\
\hline Revenue per ASK & & 2 & & & 4 & \\
\hline $\begin{array}{l}\text { Revenue per ESK } \\
\text { (equivalent seat } \mathrm{Km} \text { ) }\end{array}$ & 1 & 1 & & & 3 & 1 \\
\hline TKT's & 1 & & & & 3 & 2 \\
\hline Cargo load factor & 2 & 1 & & & 2 & 1 \\
\hline Number PAX & & 3 & & & 3 & \\
\hline Average stage length & & 3 & & & 3 & \\
\hline $\begin{array}{l}\text { Block hours per fleet per } \\
\text { day }\end{array}$ & & 2 & 1 & & 3 & \\
\hline Punctuality & & 2 & 1 & & 2 & 1 \\
\hline Regularity & & 2 & 1 & & 2 & 1 \\
\hline Number of complaints & 1 & & & 1 & 3 & 1 \\
\hline Number of lost luggage & & & & & 5 & 1 \\
\hline Perceived quality index & 1 & & & & 4 & 1 \\
\hline EBITDAR & & & & & 6 & \\
\hline EBITDA & & & & & 6 & \\
\hline
\end{tabular}

One of the first analyses we can accomplish is that all the proposed indicators in the survey are used, although with different frequencies; there is none which is not included by any airline company when preparing the budget.

Table 11 shows as well that there exist operating indicators that are budgeted monthly, by 4 of the 6 companies of the sample (for example, ASKs, RPKs, revenues per RPK and per ASK), as well as on a daily basis (in this case, 2 of 4 companies). It should be also highlighted the daily budgeting level for other important management variables, such as the number of passengers or the average stage length (fundamental for analyzing the evolution of revenues per RPK and per ASK).

Regarding economic indicators, there is unanimity when budgeting (monthly), both EBITDAR (very common and helpful in the airline business) and EBITDA. Therefore, we understand that the level of detail when budgeting is very important. With this 
in mind, the question was about which were the indicators and the frequency of obtaining them when carrying out the actual analysis of the activity. This information is given in Table 12.

Table 12. Management indicators in detail regarding the operating performance

\begin{tabular}{|c|c|c|c|c|c|c|}
\hline & \multicolumn{6}{|c|}{ Number of answers } \\
\hline & Not calculated & Daily & Weekly & Fortnightly & Monthly & Other \\
\hline ASK' & & 1 & 2 & & 3 & \\
\hline RPK's & & 1 & 2 & & 3 & \\
\hline PAX load factor & & 2 & 2 & & 2 & \\
\hline Revenues per RPK & & 2 & 2 & & 2 & \\
\hline Revenue per ASK & & 2 & 2 & & 2 & \\
\hline $\begin{array}{l}\text { Revenue per ESK } \\
\text { (equivalent seat } \mathrm{Km} \text { ) }\end{array}$ & 1 & 2 & & & 1 & 2 \\
\hline TKT's & 1 & & & & 3 & 2 \\
\hline Cargo load factor & & 2 & 1 & & 2 & 1 \\
\hline Number PAX & & 2 & 1 & & 3 & \\
\hline Average stage length & & 1 & 2 & & 3 & \\
\hline Block hours per fleet per day & & 1 & 1 & 1 & 3 & \\
\hline Punctuality & & 3 & 1 & & 2 & \\
\hline Regularity & & 3 & 1 & & 2 & \\
\hline Number of complaints & & 1 & & & 5 & \\
\hline Number of lost luggage & & & & & 6 & \\
\hline Perceived quality index & & & & & 6 & \\
\hline EBITDAR & & 1 & 1 & & 4 & \\
\hline EBITDA & & 1 & 1 & & 4 & \\
\hline
\end{tabular}

In this case, we can see that the level of analysis is higher, especially regarding the economic result. While in all of the cases EBITDA and EBITDAR have been budgeted monthly, when reporting actual data, there are two companies that do it with a higher frequency. One daily, another weekly and the remaining four companies on a monthly basis, homogenously with the budget. Another important conclusion is that while there were barely weekly budgeted indicators (mostly, as seen in Table 11, they were either daily or monthly), in the case of the analysis of actual data, there exist several analyzed indicators on a weekly basis that, probably, arise from the existence of weekly Management Committees of the companies where their operating performance is analyzed. In any case, it is seen that there exist differences between the levels of detail when preparing the budget and when analyzing the actual operational and financial indicators. This discrepancy, which is produced neither in all the companies nor in all of the variables, supposes that it is not always possible to analyze the performance of all the variables versus the budgeted data, as the budget has been carried out with another level of detail. Probably, in any case, it is feasible to carry out analysis of actual data versus homogenized weeks of previous year.

4.5. Information included in the reporting systems of the company and, where appropriate, included in the Balanced Scorecard of the company. This section is intended to analyze the obtained results related to the degree of use and criteria of development and distribution of the surveyed airlines' BSC. In the question "Does the company have an integral Balanced Scorecard?" 5 of 6 companies answered affirmatively. Likewise, it was asked if the implementation was considered profitable. Answers are shown in Table 13.

Table 13. Answer to the question: appropriation of implementation of the BSC

\begin{tabular}{|l|c|}
\hline & Number of answers \\
\hline Entirely appropriate & 2 \\
\hline Very suitable & 2 \\
\hline Suitable & 1 \\
\hline Unsuitable & 0 \\
\hline Inadequate & 0 \\
\hline Don't know/no reply & 1 \\
\hline
\end{tabular}

With different degrees, except in one case where the company did not answer the question, all the airlines think that the executed implementation of the BSC is appropriate and they are satisfied (5 of 6 respondents consider it totally appropriate, very appropriate or just appropriate).

Table 14 shows the obtained results about the differences of information included in the BSC developed by these airline companies.

Table 14. Answer to the question: information included in the BSC developed

\begin{tabular}{|l|c|}
\hline & Number of affirmative answers \\
\hline Executive summary & 6 \\
\hline Analysis of the economic environment & 4 \\
\hline Analysis of the air transportation sector & 2 \\
\hline
\end{tabular}


Table 14 (cont.). Answer to the question: information included in the BSC developed

\begin{tabular}{|l|c|}
\hline & Number of affirmative answers \\
\hline Analysis of risks and opportunities & 5 \\
\hline Goals and qualitative indicators & 5 \\
\hline Goals and quantitative indicators & 6 \\
\hline Income statement & 6 \\
\hline Cash flow statement & 6 \\
\hline Investment tracking & 5 \\
\hline Best estimate of the year-end & 6 \\
\hline
\end{tabular}

There is a great homogeneity in the answers. From 10 points proposed in the questionnaire, there exists unanimity in preparation in 5 of those and practical unanimity ( 5 of 6 surveyed companies) in the other 3. The aspects with less homogeneity are the analysis about the economic environment (still with majority, 4 of 6 companies) and, in contrast, only 2 of 6 companies included in their BSC information about the situation of the air transportation sector.

Finally, it was asked about the addressees of this management information and the results are shown in Table 15 .

Table 15. Answer to the question: distribution of the BSC

\begin{tabular}{|l|c|}
\hline & Number of answers \\
\hline Management Committee & 4 \\
\hline Chief Financial Officer & 1 \\
\hline Chief Executive Officer/First management level & 1 \\
\hline
\end{tabular}

It is seen, with nuances, that the level of distribution is very similar; 4 of 6 companies answered that the BSC is distributed to the Management Committee, in one case it is additionally distributed to the Chief Financial Officer, and in the sixth case it is distributed to the Chief Executive Officer and the first management level, being considered equivalent to the Management Committee.

\section{Conclusions}

The goal of this study was to examine the level of introduction of management accounting in Spanish airline companies, in particular the degree of strategic planning, the methods of budgeting, the procedures used to analyze results between planned and actual results, the key performance indicators used (and their frequency), given the importance of this sector in the Spanish economy and the lack of similar studies worldwide. As far as the implementation of the management accounting tools was generally extended, we could conclude that the referred companies had the required information to help in the operating, financial and strategic decision making process.

The main remarkable conclusion coming up from this research is that the level of implementation and follow-up of the main indicators of management is relatively high between the analyzed airline companies (the top six in Spain based on passengers transported in 2014). At a more detailed level, there are some aspects which should be highlighted:

- All companies consider as the main utility of management accounting the support to the decision- making process.

- The system of management accounting that has been implemented has an age between 5 and 10 years; so, it cannot be considered as a recent implementation; especially in a business that is having fast changes in their business models.

- All the respondents carry out their annual budget before the target year of budgeting and with some advance (in general, before December of $x-1$ proceed to the approval of the budget).

- The criterion of budgeting is either zero-based or incremental based, depending on the type of business.

- All the companies carry out an analysis of deviations, segregating the effects of them.

- All suggested indicators in the survey are drawn up in elder or lower frequency by the airlines management when carrying out the budget.

- The common operating indicators of the sector are budgeted even on a daily level (by 4 of the 6 companies). With regard to economic indicators, there is unanimity when budgeting (monthly) both EBITDAR and EBITDA. Therefore, we understand that the level of detail in general is very important when budgeting.

- Regarding the frequency of preparation of the actual activity indicators, one fact to highlight is that, while there were barely budgeted indicators on a weekly basis, in the case of the real data analysis, there exists multiple indicators which are analyzed on a weekly basis that, probably, arise from the existence of weekly Management Committees of the companies where they analyze the operative performance of the airline. Additionally, it has been observed that there exist differences between the level of detail when preparing the budget and the level of detail when analyzing the operating indicators.

- All the airlines have implemented a Balanced Scorecard (BSC), considering it as an appropriate tool. This highlights that there exists a big homogeneity in the sections that include the companies, as well as in the addressees of the mentioned supporting information for decision making.

As a future research line, it is proposed to extend this study taking into account international airline companies in order to detect possible similarities and/or differences with this study. 


\section{References}

1. Asociación Española de Contabilidad y Administración de Empresas (1990). Comisión de Principios de Contabilidad de Gestión. Principios de contabilidad de gestión: El marco de la contabilidad de gestión. AECA. Madrid.

2. Asociación Española de Contabilidad y Administración de Empresas (2011). Comisión de Contabilidad de Gestión. La Contabilidad de Gestión en las Empresas de Transporte Aéreo. AECA, Madrid.

3. Aeropuertos Españoles y Navegación Aérea (2015). www.aena.es (viewed day 12 April 2016).

4. Air Transport Action Group (ATAG) (2014). www.atag.org (viewed 11 April 2016).

5. Albalate, D., Bel, G. and Fageda, X. (2014). Competition and cooperation between high-speed rail and air transportation services in Europe, Journal of Transport Geography, 42, pp. 166-174.

6. Belobaba, P., Odoni, A. and Barnhart, C. (2009). The Global Airline Industry. John Wiley and Sons, Ed.

7. Button, K., Haynes, K. and Stough, R. (1998). Flying into the future: Air transport policy in the European Union. Cheltenham, UK and Northampton/Mass: Edward Elgar. In: Kiso, F. \& Deljanin, A. (Eds.). Air Freight and logistic services, Promet - Traffic \& Transportation, 21(4), pp. 291-298.

8. Campa-Planas, F. and Campa-Lewkowycz, R. (2009). Estructuras de oferta en transporte aéreo: modelos punto a punto y de red, Harvard Deusto Business Review, p. 179.

9. City Council Barcelona (2015). www.barcelona.cat (viewed 20 July 2016).

10. Confederación española de organizaciones empresariales (CEOE). Memorándum: El sector del transporte en España 2009. www.ceoe.es, 2009 (viewed 15 April 2016).

11. Daley, B. (2009). Is Air Transport Effective Tool for Sustainable Development? Sustainable Development, 17 (4), pp. 210-219.

12. Fernández, A. (1994). Situación actual y perspectivas futuras en Contabilidad de Gestión, Elementos de Contabilidad de Gestión. AECA, Madrid.

13. Ferropedia (2014). www.ferropedia.es (viewed 12 April 2016).

14. Ginieis, M., Sánchez-Rebull, M.V. and Campa-Planas, F. (2012). Los costes en el sector del transporte aéreo. Una revisión de la literatura internacional, Revista iberoamericana de contabilidad de gestión, 10, n⿳0 20 .

15. Givoni, M. and Banister, D. (2006). Airline and Railway Integration, Transport Policy, 13 ( 5), pp. $386-397$.

16. Hosteltur (2013). www.hosteltur.com, 2013 (viewed 13 April 2016).

17. Institute of Management Accounting (2016). www.imanet.org (viewed day 21 July 2016).

18. Instituto Nacional de Estadística (INE) (2011). www.ine.es (viewed day 10 April 2016).

19. International Air Transport Association (IATA). www.iata.org, 2014-2016 (viewed day 20 July 2016).

20. Ishutkina, M.A. and Hansman, R.J. (2008). Analysis of the interaction between air transportations and economic activity: A worldwide perspective. International Center for Air Transportation, MIT.

21. Lebas, M. (1993). Evolution d'un système d'information de gestion: un exemple, Revue Française de Comptabilité, 242, pp. 56-60.

22. Massachusetts Institute of Technology (MIT) (2014). Global Airline Industry Program, http://web.mit.edu/ airlinedata/www/default.html (viewed 18 April 2016).

23. Ministry of public works and transport (2013 \& 2015), www.fomento.gob.es (viewed 13 April 2016).

24. O'Connell, J.F. and Warnock-Smith, D. (2013). An investigation into traveler preferences and acceptance levels of airline ancillary revenues, Journal of Air Transport Management, 33, pp. 12-21.

25. O’Connell, J.F. and Williams, G. (2005). Passengers' perception of low cost airlines and full service carriers: A case study involving Ryanair, Aer Lingus, Air Asia and Malaysia Airlines, Journal of Air Transport Management, 11, pp. 259-272.

26. Pérez-Méndez, J.A. and Machado-Cabezas, A. (2015). Relationship between management information systems and corporate performance. Revista de Contabilidad - Spanish Accounting Review, 18 (1), pp. 32-43.

27. Porter, M.E. (1985). The competitive Advantage: Creating and Sustaining Superior Performance. NY: Free Press.

28. Porter, M.E. (1996). What is strategy? Harvard Business Review, 74 (6), pp. 61-78.

29. Reynolds-Feighan, A. (2001). Air freight logistics. In: Brewer, A., Button, K. \& Hensher, D. (Eds.). Handbook of Logistics and Supply-Chain Management. Elsevier Ltd, London, UK.

30. Statista (2015). www.statista.com (viewed 20 July 2016).

31. Sáez, A., Fernández, A. and Gutiérrez, G. (1993). Contabilidad de costes y contabilidad de gestión. Mc.Graw-Hill, Madrid.

32. World Tourism (2016). UNWTO Tourism Highlights, Edition 2016. www.unwto.org (viewed 22 July 2016).

33. Wensveen, J.G. (2015). Air Transportation - A Management Perspective. Ashgate Eighth edition.

34. Zeller, T. L. and Metzger, L.M. (2013). Good bye traditional budgeting, hello rolling forecast: Has the time come? American Journal of Business Education, 6 (3), pp. 299-310. 